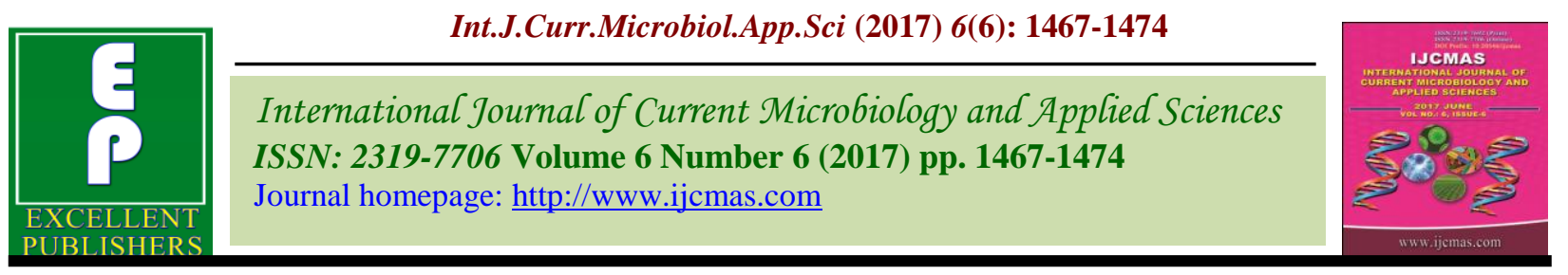

Original Research Article https://doi.org/10.20546/ijcmas.2017.606.172

\title{
Genetic Diversity Analysis among Onion Genotypes through RAPD, SSR and ISSR Markers
}

\author{
Maithilee Kesralikar*, Shekhar Mokate, B.A. Golakiya and D.N. Vakharia \\ Department of Biotechnology, College of Agriculture, Junagadh, Gujarat, India \\ *Corresponding author
}

\begin{tabular}{|c|c|}
\hline & A B S T R A C T \\
\hline \multicolumn{2}{|l|}{ Keywords } \\
\hline $\begin{array}{l}\text { Genetic diversity, } \\
\text { RAPD, SSR } \\
\text { and ISSR. }\end{array}$ & \multirow{4}{*}{$\begin{array}{l}\text { A study was conducted between the } 16 \text { onion genotypes for genetic } \\
\text { diversity analysis. The study involved the molecular techniques like RAPD } \\
\text { ISSR and SSR markers. The markers showed genetic diversity remarkably. } \\
\text { Among all markers ISSR and SSR markers gave diversified results than } \\
\text { RAPD. }\end{array}$} \\
\hline Article Info & \\
\hline $\begin{array}{l}\text { Accepted: } \\
\text { 21 May } 2017 \\
\text { Available Online: }\end{array}$ & \\
\hline 10 June 2017 & \\
\hline
\end{tabular}

\section{Introduction}

Onion (Allium cepa L.) $(2 \mathrm{n}=16)$ is one of the important bulb producing vegetable crops. The knowledge of genetic diversity in a crop species is fundamental to its improvement. However, morphological traits have many limitations, including low polymorphism, low heritability, late expression, and may be controlled by epistatic and pleiotropic gene effects (Cramer and Havey, 1999). Now a day's very powerful PCR-based techniques have also emerged which are very fast, reliable and require minimal amount of tissue for investigation. The use of molecular markers for the evaluation of genetic diversity is receiving much attention than morphological characterization. The various marker tools are Randomly Amplified Polymorphic DNA (RAPD), Simple Sequence Repeats (SSR), Inter Simple Sequence Repeats (ISSR) and Sequence Related
Amplified Polymorphism (SRAP). They have large number of applications like characterization of gene pool, DNA fingerprinting, phylogenetic analysis, molecular dissection of complex traits, and characterization of genome organization. These DNA markers offer several advantages over traditional phenotypic markers, as they provide data that can be analysed objectively. The knowledge acquired through this investigation may play a pivotal role in the application of molecular markers in onion improvement programs.

\section{Materials and Methods}

The experimental material comprised of 16 Genotypes of onion. The 2X CTAB extraction buffer was prepared by using components (2\%CTAB, 5M NaCl, 1M Tris, 0.5 M EDTA) 
and adjusting to $100 \mathrm{ml}$ with ultrapure $\mathrm{H}_{2} \mathrm{O}$. Just before use, enough volume to be used was aliquoted into a clean 50-ml tube and adds $40 \mathrm{ml}$ of $\beta$-mercaptoethanol per $20 \mathrm{ml}$ solution and the buffer pre-warm to $65^{\circ} \mathrm{C}$. Total genomic DNA was isolated from young leaves of different onion plants which were grown in pot. The DNA extraction was carried out by CTAB method as described by Doyle and Doyle (1987) with minor modifications.

Purification of DNA was carried out with RNAase treatment and DNA was analysed by agarose gel electrophoresis.

In order to perform PCR based analysis, the DNA concentration was determined by Picodrop PET01 using software v2.08 (Picodrop Ltd., Cambridge U.K). Two microlitres of DNA was held in UV transparent tip attached to micropipette used for measurement of quality at $\mathrm{A}_{260} / \mathrm{A}_{280}$ ratio which was indicated between 1.6 and 1.9. The concentration of DNA was adjusted to 50 $n g \mu l^{-1}$ for further work.

\section{Dilution of DNA for PCR}

The quantified DNA was diluted to final concentration of $50 \mathrm{ng} / \mu \mathrm{l}$ in TE buffer (10 mMTris-Cl, 1 mM EDTA, pH 8.0).

\section{Molecular markers}

For the fingerprinting of onion genotypes, various molecular marker techniques such as Randomoly Amplified Polymorphic DNA (RAPD), Inter SimpIe Sequence Repeat (ISSR) and Simple Sequence Repeat (SSR) were used. Primers required for the above techniques were synthesized from Banglore Genei,Banglore. All primers for RAPD, ISSR and SSR were diluted by adding equal amount of deionized sterile distilled water equal to its concentration. e.g. If the concentration of
RAPD primer OPA-01 was 46 nMoles then adding $46 \mu \mathrm{l}$ of deionized water made a

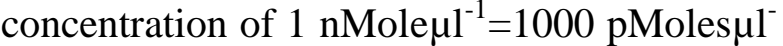
${ }^{1}$. This is kept as a stock solution of primer. By taking $5 \mu \mathrm{l}$ of stock (1000 pMoles $\mu \mathrm{l}^{-1}$ ) and $195 \mu l$ of deionized sterile distilled water gave a final concentration of $25 \mathrm{p} \mathrm{Moles} \mu \mathrm{l}^{-1}$. This working solution was used for PCR amplification of various molecular techniques.

\section{Randomly Amplified Polymorphic DNA (RAPD)}

Amplification of RAPD fragments was performed according to Ganesh et al., (2007) with some modifications using decamer arbitrary primers of OPA, OPE, OPC, OPG, OPB series. The reagents used for RAPDPCR amplification of DNA were as follows.

PCR buffer (10X) Taq DNA polymerase Bangalore Genei

dNTPs (dATP, dCTP, dGTP and dTTP) Bangalore Genei

Primer (25 p moles/ $\mu \mathrm{l}$ ) synthesised from Bangalore Genei

The appropriate amount of cocktail was dispensed to each tube and template DNA was added separately in each tube. PCR reactions for RAPD were carried out in a final reaction volume of $25 \mu \mathrm{l}$.

\section{Preparation of reaction mixture of RAPD marker}

The reaction mixture for RAPD-PCR was consisted of following reagents. PCR buffer $(10 \mathrm{X})(2.5 \mu \mathrm{l})$, Taq polymerase $(3 \mathrm{U} / \mu \mathrm{l})(0.5 \mu \mathrm{l})$, dNTPmix $\quad(2 / \mu \mathrm{l}), \quad$ primer $(2 \mu \mathrm{l})$, Template $\operatorname{DNA}(2 \mu \mathrm{l}) \quad$ Millipore sterilized distilled water $(16 \mu l)$ total volume becomes $25 \mu \mathrm{l}$. As per the given information, Millipore sterilized 
water was added first followed by addition of PCR mastermix (Bangalore Genei Pvt. Ltd.), primer in sequence and finally the template DNA. The reagents were mixed gently by tapping against the tube followed by a short spinning ( 3,000 rpm for 60 seconds). The tubes were then placed in the Thermal Cycler for cyclic amplification.

\section{PCR conditions for RAPD}

The thermal cycler was set to following cyclic condition for RAPD analysis.

\section{Electrophoresis of amplified product}

The reagents used for electrophoresis of amplified RAPD products were analysed by agarose gel electrophoresis. The concentration of agarose was $1.5 \%$ in tris buffer.

\section{Inter Simple Sequence Repeat (ISSR)}

The genomic DNA was amplified using UBC (University of British Columbia, Canada) primers. The PCR reactions for ISSR were carried according to method given by Smolik et al., (2007) with some modifications. The ISSR markers of PO2, D2, D14, HB and ISSR series were used for amplification. All the PCR reactions were carried out in $0.2 \mathrm{ml}$ capacity thin walled PCR tubes. As per the above cocktail, Millipore sterilized water was added first followed by addition of PCR mastermix (Bangalore Genei Pvt. Ltd.), primer in sequence and finally the template DNA The reagents were mixed gently by tapping against the tube followed by a short spinning ( 3,000 rpm for 30 seconds). The tubes were then placed in the Thermal Cycler for cyclic amplification conditions.

\section{Electrophoresis of amplified product}

The amplified products of ISSR were analyzed using $1.5 \%$ agarose gel.

\section{Simple Sequence Repeat (SSR)}

The genomic DNA was amplified using primers listed in table: 3.11. PCR reactions for SSR were carried out in a reaction volume of $25 \mu \mathrm{l}$ using method given by Mahajan et al., (2009) with modifications. The components for amplification of SSR primers were same as RAPD and ISSR except the primers. In SSR the amplification of reverse and forward primers were carried out. The SSR primers were of AFS series.

\section{Preparation of reaction mixture}

The reaction mixture for SSR-PCR was consisted of following reagents. PCR conditions for SSR were denaturation at 94 ${ }^{\circ} \mathrm{C}$, annealing at $92{ }^{\circ} \mathrm{C}$ and extension at $72^{\circ} \mathrm{C}$.

\section{Electrophoresis of amplified product}

The amplified products of SSR were analyzed using $2.5 \%$ agarose gel.

\section{Statistical analysis}

In order to score and preserve banding pattern photograph of the gel was taken by a Gel Documentation System, under UV transilluminator. RAPD, ISSR and SSR bands were designated on the basis of their molecular size (length of polynucleotide amplified). 100bp DNA ladder for PCR product loaded simultaneously with primer products in the gel was used to estimate the molecular size. The distance run by amplified fragments from the well was translated to molecular size with reference to molecular weight of marker. The presence of each band was scored as ' 1 ' and its absence as ' 0 '. Faintly visible bands were not scored.

Clear and distinct bands amplified by RAPD, ISSR and SSR primers were scored for the presence (1) and absence (0) for the 
corresponding band among the Genotypes. The data were entered in to MS-Excel data sheet and subsequently analyzed using NTSYS pc version 2.02 (Rohlf, 1994).

\section{Results and Discussion}

Initially, 20 RAPD primers were screened using genomic DNA of JWO-0514 genotype. As a result, 10 primers gave good amplification, were used for further amplification of DNA of all sixteen genotypes. Ten RAPD primers generated a total of 41 bands/alleles with the $80 \%$ polymorphism with an average of 4.1 bands per primer. The dendrogram generated three main clusters that consists all the genotypes grouped together in their respective subcluster. Among the screened primers OPA-01, OPE-03, OPE-11, and OPE-14, OPE-18, OPG-03, OPG-04, OPG-05 demonstrated $100 \%$ polymorphism. The average polymorphism was $80 \%$.

Screening was carried out using different 5'end anchored primers from the series of $\mathrm{D}$, HB and ISSR containing AT, GA, CT, CA, GT, CAA, ACT and GAT repeats. The part of genomic DNA that represents microsatellite repeats of a given primer were produced a highly polymorphic map (Zietkiewicz et al.,
1994). The highest $100 \%$ polymorphism was obtained with 7 primers, while four primers D2, HB12, HB13 and HB14 resulted 77.77, 66.66, 80, $66.66 \%$ polymorphism respectively. Eleven ISSR primers produced 69 bands/alleles with $90 \%$ polymorphism with an average of 6.27 bands per primer. The cluster analysis revealed the two main clusters. Jaccard's similarity coefficient showed 94\% resemblance with the dark red and red onions. $100 \%$ polymorphism was observed with the ISSR primers Viz. ISSR-2, ISSR-3, ISSR-4 as well as D14, D24, 17899B, A830241.Our data also in agreement with Smolik et al., (2007) who evaluated ISSR amplification for its applicability to onions identification. The procedure was tested on six onions and observed that out of the 30 primers 16 gave stable patterns amplifying a total of 187 loci of which 159 (85\%) were polymorphic. Clearly detectable ISSR amplicons ranged from 139 to $2213 \mathrm{bp}$ in size. Qijang et al., (2007) reported genetic diversity of 32 onion (Allium cepa L.) germplasm resources using ISSR. The genetic similarity ranged from 0.552 to 0.960 , which indicated a rich genetic diversity of onion (Allium cepa L.) germplasm resources. Present experimental results were also showed genetic similarity in the range of 0.13-0.80.

Table.1 PCR conditions for RAPD

\begin{tabular}{|c|c|c|c|}
\hline Sr.No & Step & Temperature $\left({ }^{\circ} \mathbf{C}\right)$ & Duration \\
\hline 1 & Initial Denaturation & 94 & $4.0 \mathrm{~min}$ \\
\hline 2 & Denaturation & 94 & $1.0 \mathrm{~min}$ \\
\hline 3 & Annealing & 37 & $1.0 \mathrm{~min}$ \\
\hline 4 & Extension & 72 & $2.0 \mathrm{~min}$ \\
\hline \multicolumn{4}{|c|}{ Repeat the steps 2 to 4 for 40 times } \\
\hline 5 & Final extension & 72 & $10.0 \mathrm{~min}$ \\
\hline 6 & Hold & 4 & -- \\
\hline
\end{tabular}


Table.2 Inter Simple Sequence Repeat (ISSR)

\begin{tabular}{|c|l|c|c|}
\hline Sr.No. & \multicolumn{1}{|c|}{ Step } & Temperature $\left({ }^{\mathbf{0}} \mathbf{C}\right)$ & Duration \\
\hline 1 & Initial Denaturation & 94 & $4.0 \mathrm{~min}$ \\
\hline 2 & Denaturation & 94 & $45 \mathrm{sec}$ \\
\hline 3 & Annealing & As per Tm \pm 2 & $1 \mathrm{~min}$ \\
\hline 4 & Extension & 72 & $1.30 \mathrm{~min}$ \\
\hline \multicolumn{1}{|c|}{ Repeat the steps 2 to 4 for 40 times } \\
\hline 5 & Final extension & 72 & $10.0 \mathrm{~min}$ \\
\hline 6 & Hold & 4 & -- \\
\hline
\end{tabular}

Table.3 Preparation of reaction mixture

\begin{tabular}{|r|l|r|}
\hline $\mathbf{z}$ & \multicolumn{1}{|c|}{ Reagent } & \multicolumn{1}{c|}{ Quantity } \\
\hline 1 & PCR buffer $(10 \mathrm{X})$ & $2.5 \mu \mathrm{l}$ \\
\hline 2 & Taq polymerase $(3 \mathrm{U} / \mu \mathrm{l})$ & $0.5 \mu \mathrm{l}$ \\
\hline 3 & dNTPs mix $(2.5 \mathrm{mM}$ each) & $2.0 \mu \mathrm{l}$ \\
\hline \multirow{2}{*}{4} & Primer $(25$ pmoles $/ \mu \mathrm{l})$ & $1.0 \mu \mathrm{l}$ \\
\cline { 2 - 3 } & Forward & $1.0 \mu \mathrm{l}$ \\
\hline 5 & Template DNA $(50 \mathrm{ng} / \mu \mathrm{l})$ & $2.0 \mu \mathrm{l}$ \\
\hline 6 & Millipore Sterile distilled water & $16.0 \mu \mathrm{l}$ \\
\hline \multicolumn{2}{|c|}{ Total } & $25.0 \mu \mathrm{l}$ \\
\hline
\end{tabular}

Fig.1 RAPD markers of onion genotypes generated by OPE-03

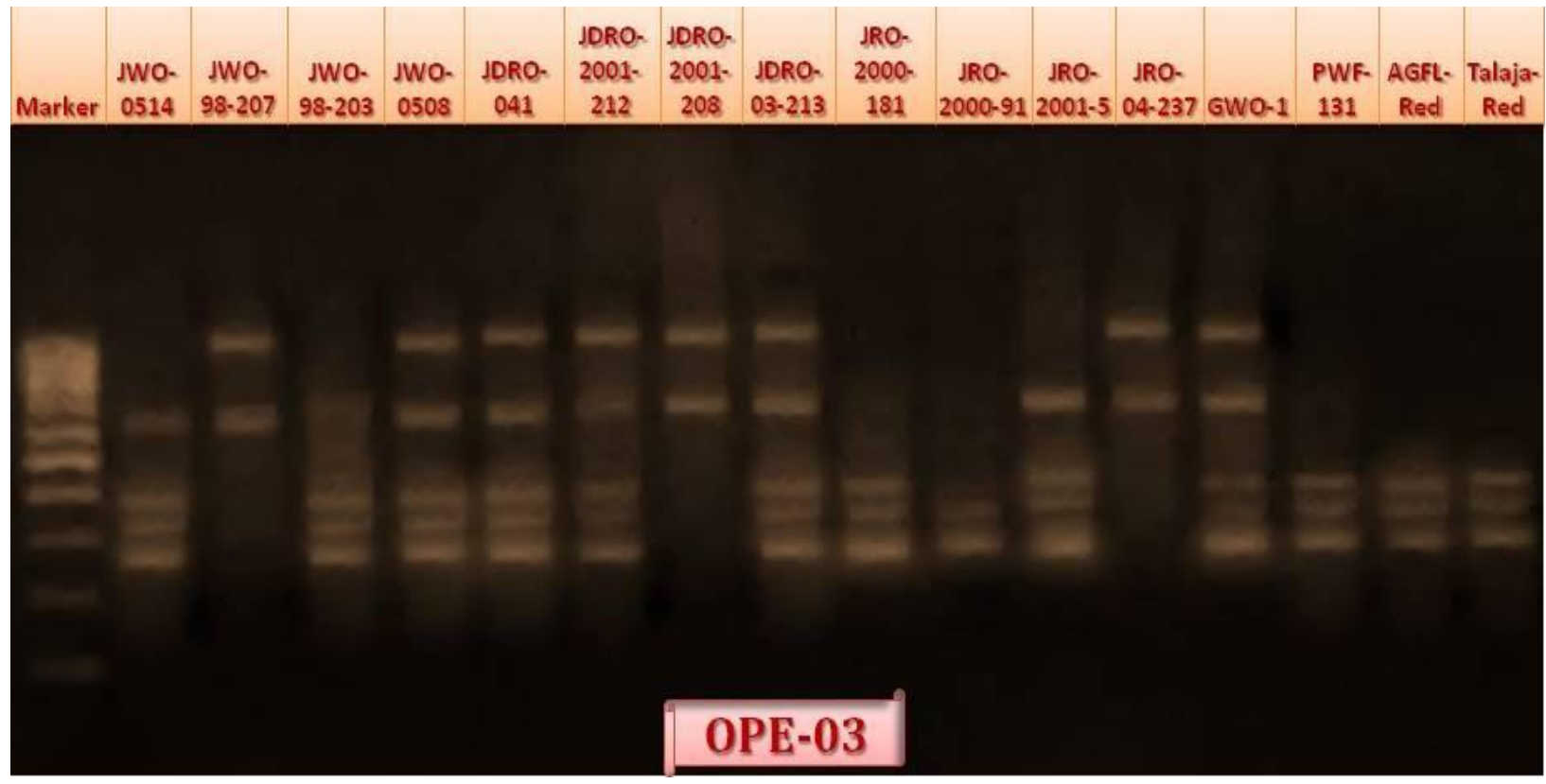


Fig.2 ISSR markers of onion genotypes generated by D-24

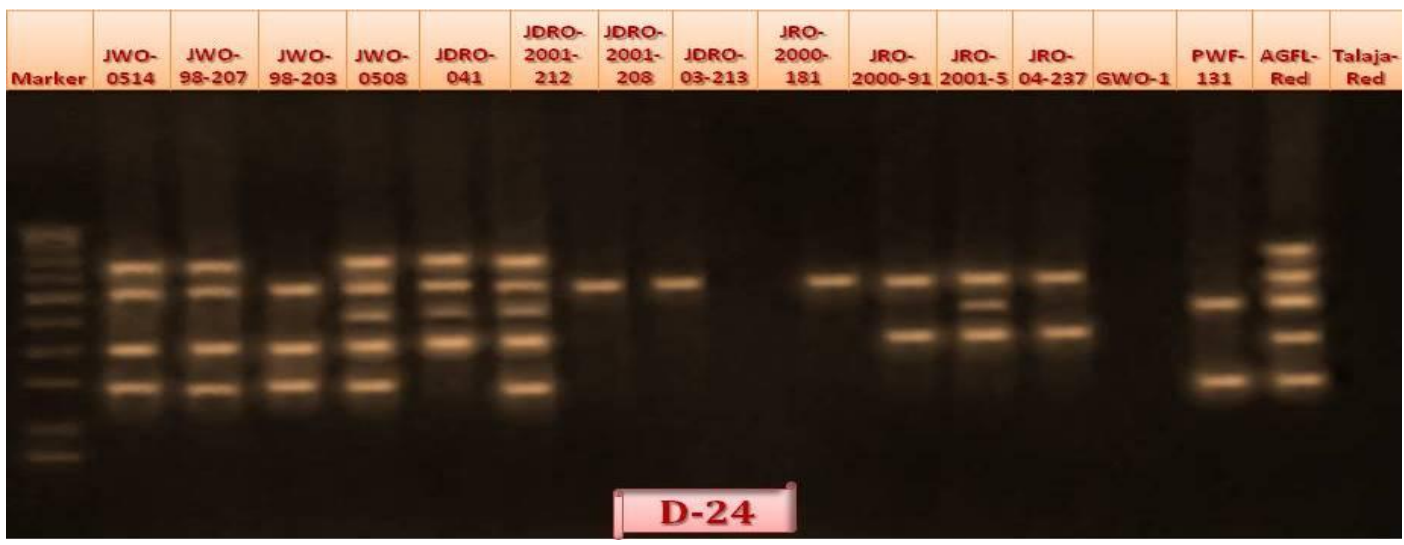

Fig.3 SSR markers of onion genotypes generated by AFS140

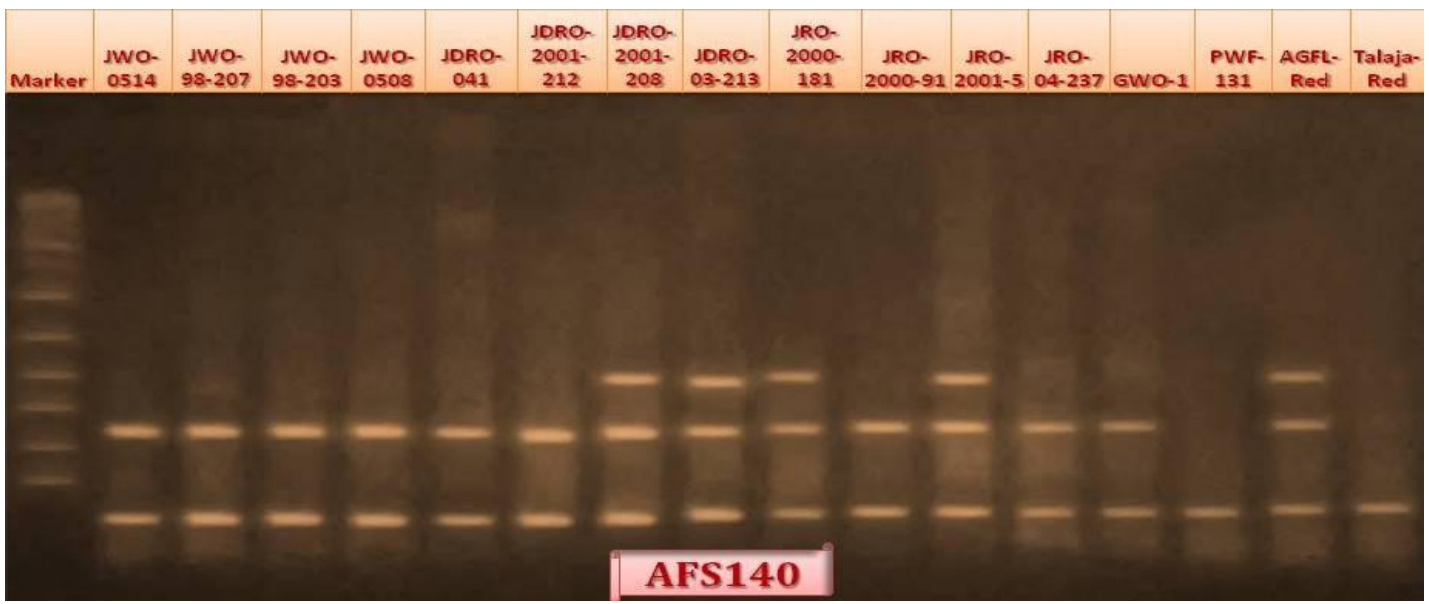

Fig.4 Dendrogram depicting the genetic relationship among 16 onion genotypes based on the RAPD data

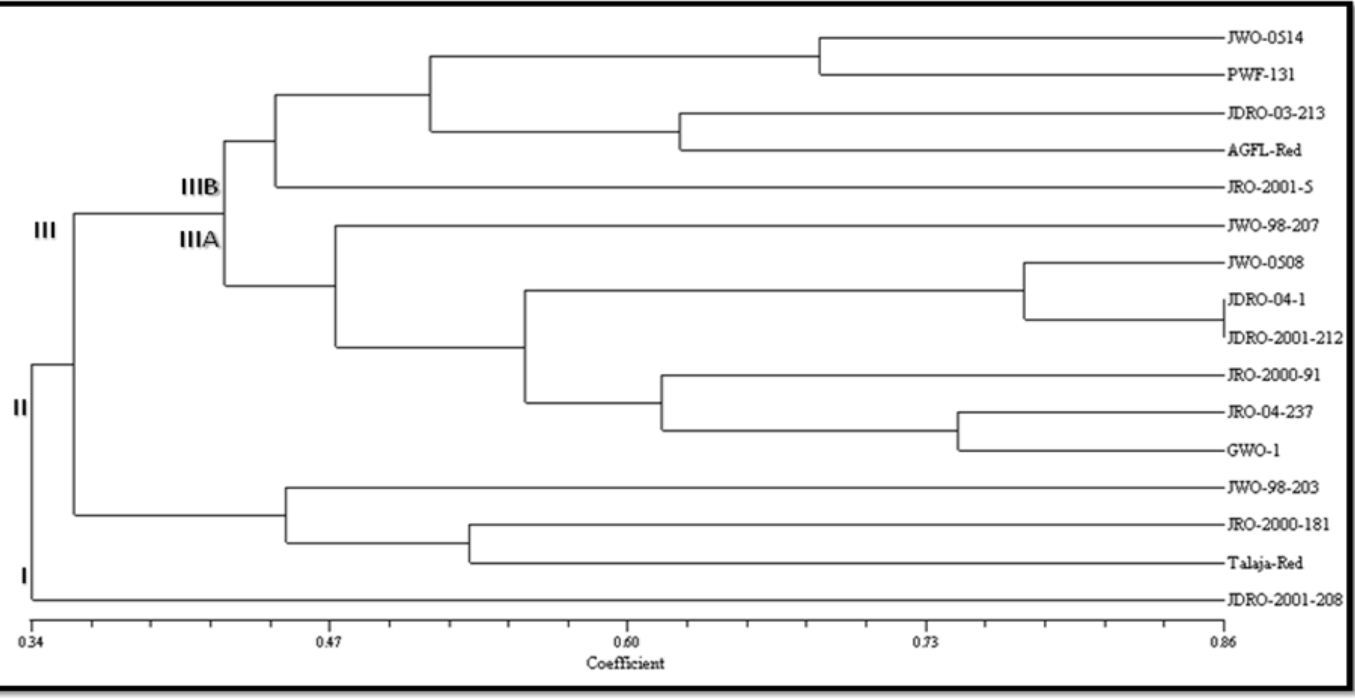


Fig.5 Dendrogram depicting the genetic relationship among 16 onion genotypes based on the ISSR data

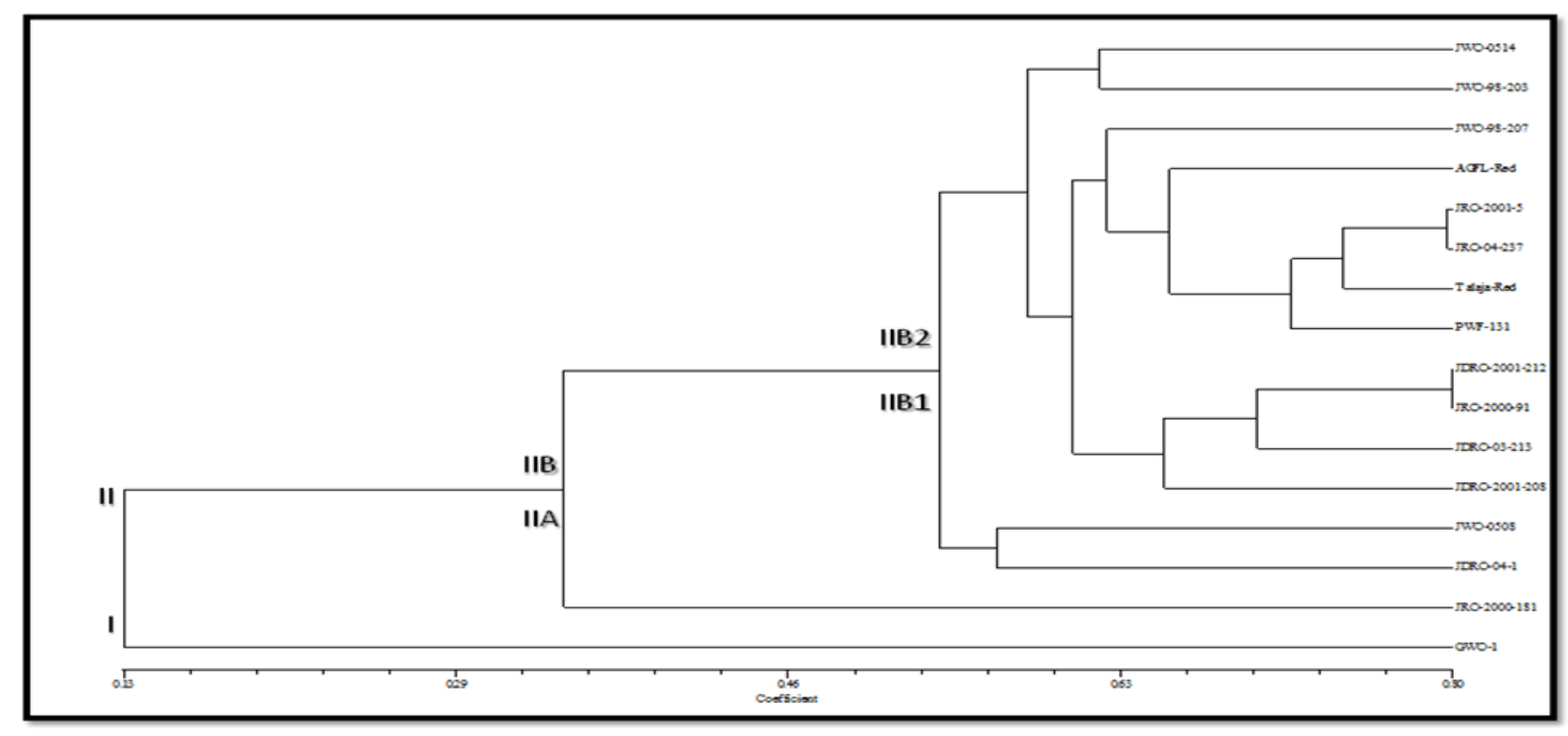

Fig.6 Dendrogram depicting the genetic relationship among 16 onion genotypes based on the SSR data

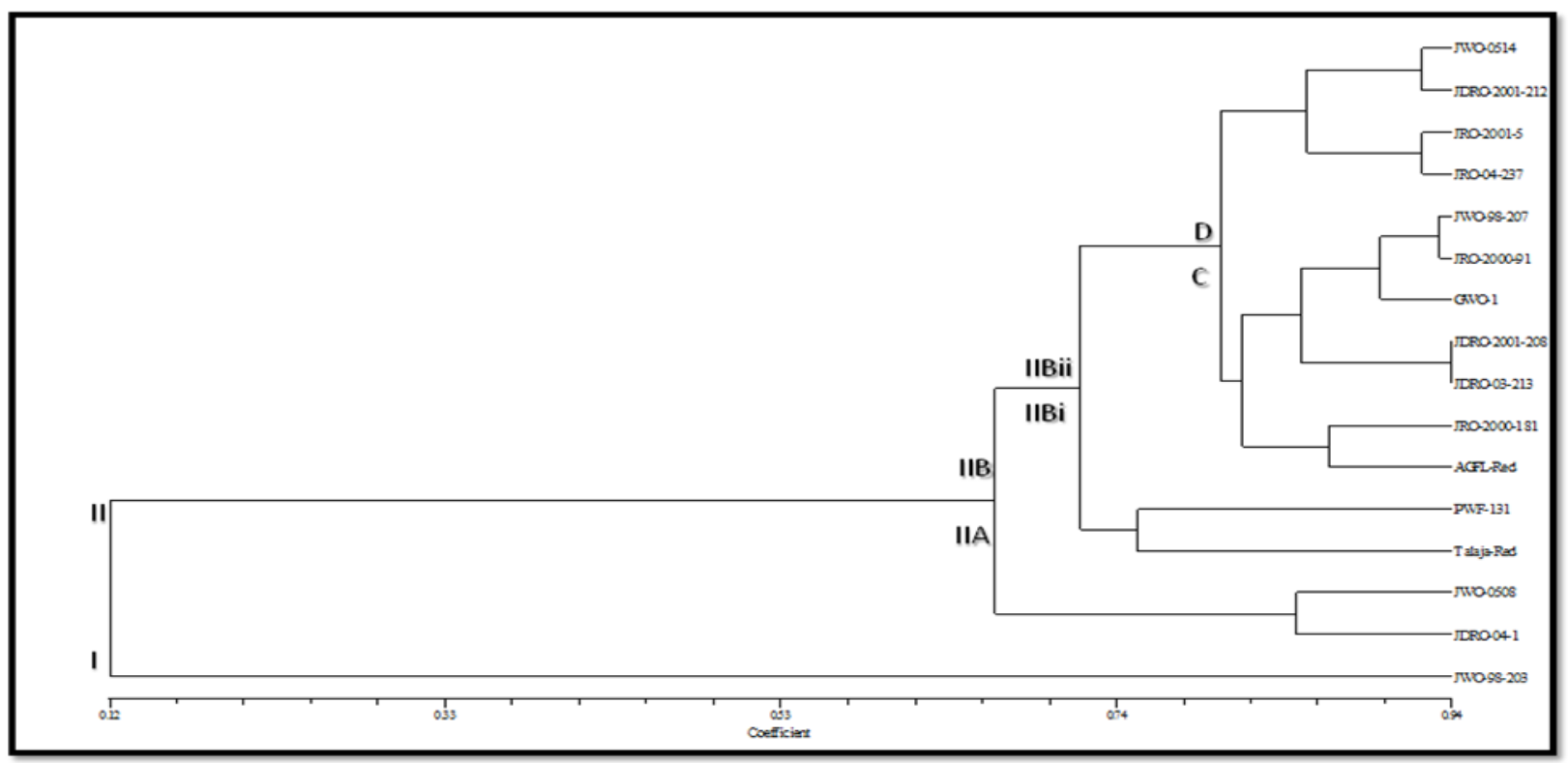

The present studies based on microsatellite (SSR) markers were used to analyze the genetic diversity among sixteen onions genotype. The fifteen primers of SSR from the AFS and ACM series were selected from the review and sequence was obtained.
Ten SSR primers out of fifteen generated total 17 bands out of which 7 bands were polymorphic. In case of SSR, $53.2 \%$ polymorphism was recorded. Sixteen onion genotypes were grouped into two main clusters and the grouping of genotypes were 
sub clustered. The SSRs amplified 10 polymorphic bands with an average of $53.2 \%$ polymorphism and 1.7 bands per primer. In case of SSRs $100 \%$ polymorphism was given by 3 primers while four primers ACM138, AFS111, AFS140and AFS039 gave 50-66\% polymorphism. Mahajan et al., (2009) revealed twenty one out of 24 loci were polymorphic and 64 different fragments were amplified in16 analysed Allium genotype. They also reported several codominant SSRs in onion.

Among the studied technique ISSR and SSR seems to be more effective than RAPD. The similarity of 16 onion genotypes was ranged from $0.34-0.86$ in RAPD, 0.13-0.80 in ISSR while $0.12-0.94$ in SSR. Thus, DNA fingerprinting techniques are more precise.

\section{References}

Cramer, C.S. and Havey, M.J. 1999. Morphological, Biochemical, and Molecular Markers in Onion. Hort. Sci., 34: 589-593.

Doyle, J.J. and Doyle, J.L. 1987. A rapid DNA isolation procedure for small quantities of fresh leaf tissue. Phytochem. Bull., 19: 11-15.
Ganesh, C.T., Gowda, V., Narayanswamy, P. and Ramanjini, G. 2007. Development of protocols for DNA Extraction and Amplification in Onion (Allium cepa L.) for RAPD analysis. Recent Trends in Horticultural Biotechnol., 2: 619-625.

Jaccard, P. 1980. Nouvelles recherchess sur la distribution florale. Bull. Soc. Vaudois Sci. Nat., 44: 223-270.

Mahajan, V., Jernej, J., Havey, M.J. and Lawande, K.E. 2009. Genetic fingerprinting of onion cultivars, using SSR markers. Indian J. Horticulture, 66: 62-68.

Qijiang, X., Chengri, C. and Tiejin, J. 2007. Genetic diversity analysis of onion (Allium cepa L.) germplasm by ISSR markers. Chinese Agri. Sci. Bull., 8: 633-636.

Rohlf, F.J. 1994. Numerical taxonomy and multivariate analysis system version 1.80 manual. Exeter Software, New York.

Smolik, M., Rzepka, P., Kowalczys, K. and Grabiec, M. 2007. Study of genetic diversity of the onion species by issr-pcr analysis, Acta Scientiarum Polonorum Biotechnologia, 6: 13-21.

\section{How to cite this article:}

Maithilee Kesralikar, Shekhar Mokate, B.A. Golakiya and Vakharia, D.N. 2017. Genetic diversity analysis among onion genotypes through RAPD, SSR and ISSR markers. Int.J.Curr.Microbiol.App.Sci. 6(6): 1467-1474. doi: https://doi.org/10.20546/ijcmas.2017.606.172 